\title{
Integration Policy Concerning Temporary Labor Migrants as a Part of Geoeconomical Strategy of Russia in Eurasia
}

\author{
Tkachenko Marina
}

\author{
PhD., Dr. Economics, Chief Researcher of Market Economy Institute of Russian Academy of Sciences,
} Laboratory of Spatial Development

\section{Doi:10.5901/ajis.2013.v2n8p199}

\section{Abstract}

Recently Russia joined the countries depending on inflow of foreign labor force. We concluded that immigration into Russia from main countries of origin was chaotic. Attempts of its regulation are unilateral, and depend on Russian side only. Countries of origin "push" their inhabitants trying to solve financial and social issues at the expense of migrant population. But Russia gets significant costs such as illegal migration, social conflicts increase and outflow of the part of money supply from host country. Recently approved Conception of Migration Policy makes the Government of Russia responsible for labor migrants exclusively, without taking into consideration the responsibility of other actors of foreign labor force market (including authorities of countries of origin) to take part into the integration of temporary labor migrants in host country. It requires fundamentally new approaches to research of emigration potential of countries of origin and immigration potential of host country in respect to economic and demographic capacity on host country, settlement policy of migrants and arrangement of much more comfort conditions for them in the aggregate with decrease of potential sources of conflict on the territory of migrants settlement and occupation. We consider that Russia should apply several new methods of economic, financial and social stimulation of participants of foreign labor force market in Russia. These methods allow to work out consolidated model of integration policy concerning temporary labor migrants and to make responsible for integration policy both host country and states of origin.

\section{Introduction}

State integration policy is based on the evaluation of criteria which are indexes of country attraction for migrants and comfort of conditions of their entrance, residence and employment in the territory of host country. It being known that unlike adaptation the efficiency of integration is also willingness of local inhabitants to share immigrant values, cultural norms and rules of behavior.

Index MIPEX, developed by British Council and Migration Policy Group, contributes to analysis of the integration policy using seven criteria: labour market mobility; family reunion for third-country nationals; education; political participation; long-term residence; access to nationality; anti-discrimination.

It should be paid much attention to such aspects of temporary migrants integration in Russia: access to labor market and labor discrimination; labor migrant's desire to have permanent residence in Russia, bring the family into Russia, to get residence permit and citizenship. Integration of foreign temporary labor migrants and permanent migrants in Russia (living more than 3 years according to Russian legislation) has its own features. Many migrants, being temporary labor migrants, may stay for long terms in Russia or move from origin countries and to Russia from time to time.

Former investigations based on MIPEX demonstrated that Russia is the country from the group of states with "varied exclusion" (Prokhorova, 2011). This approach to migrant's integration includes precise differentiation of rights and opportunities between temporary migrants and citizens of the country. Migrants are considered to be like temporary labor resources without permit for permanent residence: they are successfully involved in the labor market but don't have many civilian rights, for example, political ones. The principal feature of varied exclusion" approach is employment of illegal labor migrants who can't protect their rights (Schierup, Hansen \& Castles, 2006).

Relying on former investigations of various researchers (Bommes \& Morawska, 2005; Carrera, 2006; Drobigeva, 1998; Iontsev \& Ivakhnyuk, 2013; Mukomel', 2012; Penninx, 2005; Vasilyeva, 2010; Vermeulen, 1977), it should be noted that the most important types of integration are linguistic, cultural, social and economic ones.

Linguistic integration is acquirement of official language of host country, its active use in various living situations.

Cultural (social) integration is acquirement of rights and opportunities by migrants equal to residents ones to get residence permit, protect from discrimination, take part in political life and reunite with family. 
Economic integration is active involvement of migrant in economical relations on the basis of parity relations with residents. It relates to equal rights in access to labor market, getting equal payment for equal work, getting education, and other rights.

Efficiency of these types of integration will be considered in the paper.

\section{Background: Tendencues in Labour Immigration into Russia}

Russia has joined the countries depending on foreign labor force recently. In 2011, according to official statistical data, migrant inflow from CIS came to 356535 persons, it being known that the greatest part of labor migrants come from Uzbekistan (20,8\%), following the Ukraine (12,2\%), Kyrgyzstan (11,7\%), Kazakhstan $(10,2 \%)$, Tajikistan $(9,8 \%)$. There is tendency for increase of migration inflow despite of declarations of future demographic resources lack and exhausting of source of cheap labor force from Central Asian states correspondingly. Taking into account that the most migrants come to Russia from the Central Asia, we intend to evaluate the efficiency of integration of temporary labor migrants from this region. Significant intensity of migration movement of labor force from the Central Asia to Russia bears the necessity in adequate integration policy with respect to coming unskilled labor force and responsiveness of local community interests. The significance of migration from the Central Asia towards Russia is very great. Russia faces with continuous inflow of Russians from this region, but at the same time the proportion of title nations of the region (Tajik, Uzbek, Kirghiz, Kazakh, Turkmen) increases rapidly in migration outflow towards Russia. For example, during the first decade of XXI-century every third migrant from Tajikistan, who arrived and settled in Russia, belonged to title nationalities of the Central Asia region, for migration exchange with Kyrgyzstan - every tenth was the representative of title nationalities, and with Uzbekistan - only every eighteenth. Approximately 30 thousand students from Central Asia study in Russian high schools. Many of them have a job, representing transitional group among scholar and labor migrants. In 2010, about 1.5 million regular temporary labor migrants from Central Asia worked in Russia, and it reached 60 percent of all the foreign labor force (Ryazantsev, 2007).

Studies demonstrate that over the past decade migration activity of population in Central Asian states increased rapidly. New socio-demographic categories of population were involved in migration flows. In particular, rural inhabitants, women and young men began to take active part in the migration. It being known that demographic disparity among $\mathrm{CIS}$ countries has great impact on migration outflow growth from Central Asia. Russia faces great issues with natural reproduction whereas population in Central Asia has continuous growth. Over the past decade the substantial population increase was typical for Uzbekistan, where the population increased from 24,5 million persons to 27,1 million persons (since 2000 till 2008). Uzbekistan is the most multi-populated country from the Central Asia region, where birth rate is 2,5 child per a woman (on the average for the period since 2005 till 2010). The highest birth rate is in Tajikistan $-3,3$ child per a woman in childbearing age. Since 2005 till 2010 the population in Tajikistan increased from 6,1 million to 7,2 million persons. Kyrgyzstan and Turkmenistan demonstrate the same birth rate, but the increase of population was less than in Tajikistan. Kazakhstan has the least birth rate - only 1,9 child per a woman in childbearing age, but increase of population was registered (from 14,9 million to 15,6 million persons).

Till 2020 the size of population in CIS will rise and amount 282 million peoples. But increase will be uneven. Uzbekistan, Kyrgyzstan like two main suppliers of labor force into Russia, and also Turkmenistan will be the main demographic leaders.

Taking into account extreme differentiation of migration flow, labor migrants make a lot of problems for residents and authorities. However, there are several backgrounds, which allow to use potential of migrants from the Central Asia more productively comparing with emigrants from the countries of Far abroad. It's determined by the following factors:

1. Cultural and historic factor. Eurasian migration system has predominantly emerged in the borders of the former Soviet Union. Socio-economic links between national republics and Russian language spread became the fundamental basis of USSR creation and genesis. It's evidently that citizens of Central Asia choose Russia as a host country, taking into consideration that Russian language proficiency and understanding the mentality increase the chance for job placement in Russia.

2. Political factor. Eurasian integration enlargement gives an opportunity for free movement of Eurasian Economic Commonwealth residents in borders of this integration grouping. In present time citizens of Tajikistan, Kazakhstan, Uzbekistan, Kyrgyzstan, excluding Turkmenistan, have free entrance into Russia. Customs Union (Russia, Byelorussia, Kazakhstan) with its future members including Kyrgyzstan and Tajikistan, on the one hand, promotes legalization of temporary labor migrants from Central Asia on the territory of Russia, and on the other hand, facilitates their arrival and employment in Russia which determines 
the increase of migration inflow into Russia. At the same time, the Government of Uzbekistan doesn't approve of its state accession into Customs Union and condemn its citizens for problems with Russian legislation in the case of violation of rules of visa, border or migration control.

3. Reduction of barriers in acceptation of labor migrants and members of their families will bring out of the shadow the significant part of migration flow, but the main actors of the foreign labor force market will keep on responsibility for adaptation of labor migrants on the Russian territory.

Social factor. Sustainable "migration networks", based on social contacts, relative and social communications, developed in Russia. As different studies show, the major part of labor migrants from Central Asia get fixed up in a job using social networks and private agents. At the same time, the part of state offices and private employment agencies is considered to be very insignificant. It's undoubtedly that similar networks became important elements of successful integration of temporary labor migrants in Russia.

On the other hand, geopolitical proximity of Russia to the states of Central Asia reinforces illegal migration flow, what complicates integration of temporary labor migrants in Russia and their account by migration authorities. Besides, there are some internal issues un Russia preventing successful integration of citizens from Central Asia in the host country.

\section{Results and Discussions}

Our research results demonstrate that effectiveness of integration of temporary labour migrants is extremely unfavorable.

Using content-analysis for studying of principal elements of integration (access to labor market and work satisfaction; absence of work discrimination; issues in getting of citizenship and permit for residence; desire for permanent residence and conditions of residence; existence of linguistic issues; opportunity of political activity; opportunity for family reunion; access to education and healthcare services; communication with authorities and law), we concluded:

1. The work discrimination is the most important problem which lies in absence of legal labor contracts and guarantees of employment and social provision. The issues in the field of medical care and dwelling are the greatest for labor migrants from Central Asia.

2. Extreme bureaucracy in getting of legal documents, problems with communications with authorities and power structures. The number of crimes, committed with emigrants from Central Asia, increases. It especially relates to those migrants who lost job and didn't intend to leave Russia.

3. Russians neglect natives from Central Asia, feeling threads from them. Such emotions bear intolerance and negative relation to the temporary labor migrants. Although many Russians find that the country needs in labor of migrants in some fields of the economic, but at the same time about $56 \%$ of Russians are not able to live near the families of labor migrants, work together with them, to led own children in the same school with the children of Central Asia emigrants. Thereby many residents advocate the limitation of labor migrants entrance using quotas, organized engaging and etc.

4. By expert's opinion, residents from Central Asia consider the job placement in Russia as a strategy of life success since childhood. At the same time, many of them come to Russia alone, working here and sending solid remittances to homeland. Only about 14 percent of temporary labor immigrants wish to get citizenship in Russia by any channel (education, marriage, etc.). However, over last years we may observe the tendency when labor migrant comes to Russia with family, and his children became more successful in integration into host society.

5. By expert's estimates, many of labor migrants from Central Asia live illegally on the territory of Russia, at the same time many have legal entrance and legal labor contract, but often stay over the terms of contract and violate Russian legislation - so, they became irregular (illegal) migrants. Concern of Russian Government relative to labor migrants from Central Asia is linked with impossibility to account their exact number.

6. It's evidently that residents from Central Asia can't take part in Russian political life, but their significant number in Russian economics forces Government of Russia to be more diplomatic in its geopolitical strategy.

7. Compact living is inhere for emigrants from Central Asia, their social circle is limited to the alignment of communication with the employer, the owner of the dwelling, the law enforcement authorities and Federal Migration Service. Most successfully adapted are those who speak Russian well, but there are practically no such representatives among the migrants of new generation 


\section{Conclusions and Policy Implications}

We conclude that immigration into Russia from the principal countries of origin was chaotic. Attempts of its regulation were unilateral and depended mainly on Russia. Countries of origin "push" their citizens, trying to save financial and social issued at the expence of migrant population. However, Russia faces significant costs as illegal migration, increase of social conflicts and outflow of the part of money supply from host country. Temporary labor migrants themselves face significant issues with integration into host community. None of the types of integration can't be called as a success.

Besides, approved Conception of Migration Policy till 2020 has inadequate view at the organizational system of promotion to foreign workers, doesn't consider migration filters for limitation of unskilled labor force flows. Besides, the Conception makes responsible only the Government of Russian Federation for the integration of temporary labor migrants, and doesn't pay attention for responsibility of other actors of foreign labor force market to take part in integration of labor migrants, including authorities of the countries of origin. Besides, in Russia there is no acknowledged model of integration policy by society and state, whether it is to be its own model or borrowed from other countries importing labor force. The situation is complicated by the fact that the majority of migrant workers in Russia stays illegally with violation of the rules of visa, border and migration control.

Should be developed a new model of integration of labor migrants in Russia with the commonality of socio-cultural, political and economic values of the major donor countries and the host country.

This will require the use of new approaches in the study of emigration potential of donor countries and the capacity of the host countries from the point of view of economic and demographic burden on the host community, the policy of resettlement of migrants and creating of more comfortable environment of their living conditions together with a reduction of potential sources of conflict in the territory of their residence and employment. Designed with regard to Russian conditions model of integration of temporary labor migrants should be a system of multi-level adaptation, including intergovernmental dialogue at the level of the federal government, provincial, municipal levels of government, as well as specific employers experiencing labor shortages. Preparation of worker for life in Russia must start in the country of its outcome, it's necessary to to find such incentives that may encourage the donor country on the basis of equal relations with Russia to tale material, financial and social participation in the formation of the integration policy in relation to its own nationals.

The mechanism of equal economic relations is to develop a scheme of distribution of powers between the actors of foreign labor force market (donor governments, the government of the Russian Federation as the host country for temporary labor migrants, regional governments and municipal governments, business and NGO's, Diaspora and the media) and the provision for them financial, material, production and technological and social benefits in their implementation of the mechanism of integration policies that will promote these areas of work for temporary labor migrants as the policy of settlement with provision of dwelling for migrants, employment and socio-cultural adaption of migrants in the host community,

\section{References}

Bommes, M., \& Morawska E. (eds.) (2005). International Migration Research: Constructions, Omissions and the Promises of Interdisciplinarity. Aldershot: Ashgate

Carrera, S. (ed.) (2006). The nexus between immigration, integration and citizenship in the EU. CHALLENGE Collective Conference Paper, April 2006. Retrieved from: http://www.ceps.be.

Drobigeva, L. (1998). Social and cultural distance. The experience of multinational Russia. Moscow, Institute of Sciology of Russian Academy of Sciences.

Iontsev, V.,\& Ivakhnyuk I. (2013). Models of migrants integration in modern Russia. CARIMEast: European University Institute, 22 p.

Mukomel', V. (2012). Labour Migration And The Host Country: Russian case. CARIM-East Research Report 2012/31, 2012, European University Institute, Robert Schuman Centre for Advanced Studies. Retrieved from: http://www.carim-east.eu/media/CARIMEast2012-RR-31.pdf

Penninx, R. (2005). Integration of migrants: economic, social, cultural and political dimensions. In M. Macura, A.L. MacDonald \&W. Haug (Ed.), The new demographic regime. Population challenges and policy responses. New York/Geneva: United Nations, 137-152.

Prokhorova, A. (2011) Integration policy relates to migrants in Russia: example of evaluation using index of integration MIPEX. Demoscope weekly, 26-th September - 9-th October (479-480). Retrieved from: http://demoscope.ru/weekly 12011/0479/analit05.php

Ryazantsev, S. (2007). Labor migration in CIS and Baltic States: tendencies, consequences, regulation. Moscow: Formula prava

Schierup, C.-U., Hansen, P. \& Castles, S. (2006). Migration, Citizenship and the European Welfare State: European Dilemma. New York: Oxford University Press, 41-45

Vasylieva, T.A. (2010). Migration policy, citizenship and foreigner status in the states of Western democracy. Moscow: Institute of Public 
Policy

Vermeulen, H. (ed.) (1977). Immigrant policy for a multicultural society. A comparative study of integration, language and religious policy in five Western European countries. Brussels/Amsterdam: MPG/IMES. 